\title{
Pharmacognostical, Physicochemical and Phytochemical Evaluation of Strobilanthes kunthianus (Acanthaceae)
}

\author{
Geetha Balasubramaniam ${ }^{1,2, *}$, Mahendran Sekar ${ }^{3}$, Shrishailappa Badami ${ }^{4}$
}

Geetha Balasubramaniam ${ }^{1,2, *}$, Mahendran Sekar ${ }^{3}$, Shrishailappa Badami $^{4}$

'Department of Pharmaceutical Chemistry, Swamy Vivekanandha College of

Pharmacy, Elayampalayam, Tiruchengode - 637205, Tamilnadu, INDIA.

${ }^{2}$ Department of Pharmaceutical Chemistry, JSS College of Pharmacy, JSS Academy of

Higher Education and Research, Rocklands, Udhagamandalam - 643001, Tamilnadu, INDIA.

${ }^{3}$ Department of Pharmaceutical Chemistry, Faculty of Pharmacy and Health Sciences, Universiti Kuala Lumpur Royal College of Medicine Perak, Ipoh - 30450, Perak, MALAYSIA.

${ }^{4}$ Chaitanya Vikas Yoga \& Nature Cure Centre, Rajatgiri, Dharwad -580004, Karnataka, INDIA.

\section{Correspondence}

Prof. Dr. Geetha Balasubramaniam

Department of Pharmaceutical Chemistry, Swamy Vivekanandha College of Pharmacy, Elayampalayam, Tiruchengode -637205 ,

Tamilnadu, INDIA.

Phone no: +91-9629842539;

E-mail: saranblue69@gmail.com

History

- Submission Date: 04-04-2020;

- Review completed: 15-04-2020;

- Accepted Date: 06-05-2020;

DOI : 10.5530/pj.2020.12.106

Article Available online

http://www.phcogj.com/v12/i4

\section{Copyright}

(C) 2020 Phcogj.Com. This is an openaccess article distributed under the terms of the Creative Commons Attribution 4.0 International license.

\section{ABSTRACT}

Objective: The present study aimed to evaluate pharmacognostical, physicochemical and phytochemical evaluation of various parts of Strobilanthes kunthianus. Methods: Macroscopical, microscopical, physico-chemical and phytochemical evaluations of leaves, stem, root and flowers of $S$. kunthianus were investigated. The paraffin embedded specimens were sectioned with the help of Rotary Microtome. The thickness of the sections was 10-12 $\mu \mathrm{m}$ and dewaxing was done by customary procedure. The sections were stained with toluidine blue for microscopical analysis. The preliminary phytochemical study was carried out for various extracts of S. kunthianus using standard procedure. Results: In the pharmacognostical, physicochemical and phytochemical studies, in an attempt to standardize the leaves, stem and root of $S$. kunthianus have been shown that will be definitely useful to the future researchers for the identification of the plant. Conclusion: These studies offer referential evidence for accurate identification and standardization of S. kunthianus.

Key words: Strobilanthes kunthianus, Pharmacognostic standardization, Physico-chemical evaluation, Phytochemical analysis.

\section{INTRODUCTION}

Medicinal plants and its isolated compounds have been the basis of treatment of many human ailments. The history of medicine dates back essentially to the survival of human civilization. The currently recognized modern medicines has been steadily established over the centuries by systematic and observational hard work of scientists. However, the basis of its development remains imbedded in traditional herbal medicine and therapies. The history of medicine includes many ridiculous therapies. Nevertheless, ancient knowledge has been the basis of modern medicines and will remain as one significant source of future medicine and therapeutics. However, difficulty behind the recognition of an alternative medicines in developed countries is the lack of documentation and strict quality control measures. So that the documentation and standardization of the raw materials used in herbal medicine is very essential for the worldwide acceptance of this system of medicine.

Pharmacognostical studies serve as an important tool in plant identification. Detailed microscopic evaluation will be of immense importance in the standardization of plant materials. Isolation of phytoconstituents from the active extracts helps in many ways in plant research. These constituents can serve as marker compounds for their standardization. The determination of the biological activities helps in developing these compounds into drugs or lead molecules for further drug development. Pharmacognostic standardization and physico-chemical analysis were globally accepted in identification and authentication of the genuine plant materials. Correct identification and quality assurance of plant materials are indispensable to ensure reproducible outcome of herbal medicines, which will contribute to its safety and efficacy. Pharmacognostic standardisation of plant material include its morphological, anatomical and biochemical characteristics.

There are over 200 species of Strobilanthes nearly all in Asia and over 150 occurs in India, especially in Western Ghats and Nilgiris alone claims more than thirty species. Many of the species flower at longer intervals such as between six and twelve years, usually and in some even after 35 years. There exists a strong chemotaxonomical relationship among the genus. Species of Strobilanthes grow wild on the Nilgiri ranges between 6000 to 7000 feet. The genus Strobilanthes is known for its various biological activities. $^{2-7}$

S. kunthianus (Neela kurinji) is a shrub in the grasslands of Western Ghats in India. The Nilgiris, which literally means the blue mountains got its name from the purplish blue flowers of Neela kurinji that blossoms gregariously once in twelve years. $S$. kunthianus is well known for its medicinal properties. It was reported to possess many biological activities including anti-inflammatory and anti-osteoarthritic, analgesic, antioxidant, antibioflim, enzyme inhibitor, central nervous depressant, antigiardial, antifungal, antibacterial, antiseptic, antimicrobial, cytotoxicity and protect skin against UV. ${ }^{8-14}$

However, there is no scientific standards or pharmacognostic parameters are yet available to determine the quality of this crude drug. Thus, the present study was designed to evaluate the pharmacognostic, physicochemical and phytochemical parameters of various parts of $S$. kunthianus.

Cite this article: Balasubramaniam G, Sekar M, Badami S. Pharmacognostical, Physicochemical and Phytochemical Evaluation of Strobilanthes kunthianus (Acanthaceae). Pharmacogn J. 2020;12(4):731-41. 


\section{MATERIALS AND METHODS}

\section{Plant material}

The whole plant of S. kunthianus was collected from Thalaikuntha region, near Udhagamandalam, Nilgiris district, Tamilnadu, India. The plant was identified and authenticated at Botanical Survey of India, Coimbatore, Tamilnadu, India. Different parts of S. kunthianus was shown in Figure 1. The plant profile of S. kunthianus is shown in Table 1.

\section{Pharmacognostical evaluation}

\section{Anatomical characterization}

The different organs viz., root, stem, leaf and flowers of $S$. kunthianus were cut and removed from fresh healthy plants and fixed in FAA $(5 \mathrm{ml}$ of formalin $+5 \mathrm{ml}$ of acetic acid $+90 \mathrm{ml}$ of $70 \%$ ethanol). After $24 \mathrm{~h}$ of fixing, the specimens were dehydrated with graded series of tertiarybutyl alcohol as per the schedule..$^{15}$ Infiltration of the specimens was

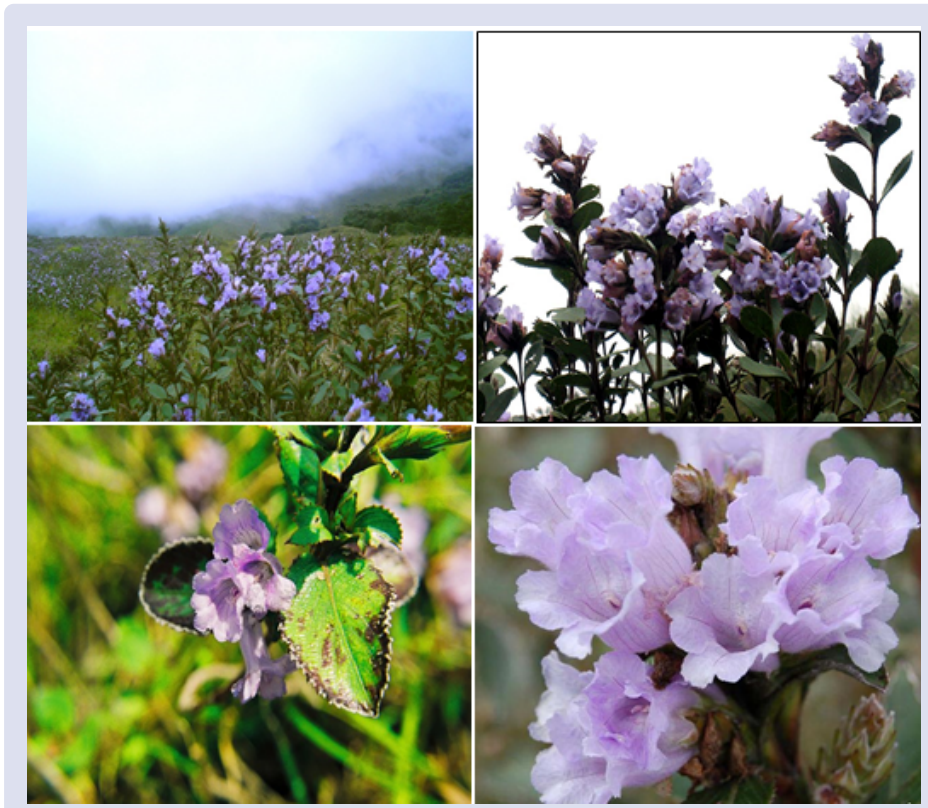

Figure 1: Different parts of $S$. kunthianus.

Table 1: Plant Profile of S. kunthianus.

\begin{tabular}{|c|c|c|}
\hline 1 & Botanical name & Strobilanthes Kunthianus Nees T Anders \\
\hline 2 & Family & Acanthaceae \\
\hline 3 & Synonyms & Phlebophyllum Kunthianus, Strobilanthes Kunthianus, Strobilanthes Nilgirianthsis, Phlebophyllum Kunthianus \\
\hline 4 & Vernacular Names & Tamil - Neelakurinji, kurinji \\
\hline 5 & Distribution & It is found in Western Ghats, The Nilgiris and the Palnis, and the hills of Keralaabove $1800 \mathrm{~m}$ on grassy downs. \\
\hline 6 & Description & $\begin{array}{l}\text { Bushy shrub, } 1-2 \mathrm{~m} \text { high, in stray clumps or gregarious; stems numerous, erect, quadrangular; nodes prominent. Leaves } \\
\text { elliptic-ovate, ca } 5 \times 2.5 \mathrm{~cm} \text {, acute at base, crenate-serrate at margin, acute at apex, coriaceous, scabrid above, white- } \\
\text { villous between veins beneath; secondary veins } 8 \text { or } 9 \text { pairs, prominent; petioles ca } 5 \mathrm{~mm} \text { long. Inflorescences spikes, } \\
\text { uninterrupted, sometimes branched, ca } 8 \mathrm{~cm} \text { long, supported by leafy bracts, white-villous; bracts elliptic-ovate, ca } 1.2 \\
\mathrm{~cm} \text { long, acute at apex, white villous, floccose at margin and middle. Calyx ca } 1.2 \mathrm{~cm} \text { long, floccose-villous; segments } \\
\text { linear-lanceolate, connate almost half way from base. Corolla tubular ventricose portion gradually expanding from base, } \\
\text { hairy inside; lobes } 5 \text {, orbicular, entire. Stamens } 2 \text {, included, monodelphouus; filaments ca } 7 \mathrm{~mm} \text { long, pilose; stamina } \\
\text { sheath extending just above cylinder base. Ovary glabrous but hairy at tip; style ca } 1.5 \mathrm{~cm} \text { long, included, hairy. Capsules } \\
\text { oblong, ca } 1.2 \mathrm{~cm} \text { long, } 4 \text {-seedded; seeds orbitular; ca } 1.5 \mathrm{~mm} \text {, complanate, densely hairy and hairs spreading when wet } \\
\text { except on basal circular areole. }{ }^{24}\end{array}$ \\
\hline 7 & Parts used & Root, stem, leaves and flowers \\
\hline 8 & Ethnomedical information & No ethnomedical information available \\
\hline 9 & $\begin{array}{l}\text { Chemical constituents and } \\
\text { biological properties }\end{array}$ & $\begin{array}{l}\text { No chemical constituents are reported. It was reported to possess biological activities including anti-inflammatory } \\
\text { and anti-osteoarthritic, analgesic, antioxidant, antibioflim, enzyme inhibitor, central nervous depressant, antigiardial, } \\
\text { antifungal, antibacterial, antiseptic, antimicrobial, cytotoxicity and protect skin against UV. }{ }^{8-14}\end{array}$ \\
\hline 10 & Other Strobilanthes species & $\begin{array}{l}\text { S. crispus, S. callosus, S. ixocephala, S. auriculatus, S. discolor, S. cusia, S. cuspidatus, S. foliosus, S. consanguineus, S. } \\
\text { gossypinus, S. pulneyensis, S. perrottetianus, S. papillous, S. neilgherrensis, S. wightianus, S. urceolaris, S. sessilis, S. asper, S. } \\
\text { zenkerianus, S. mincranthus, S. luridus, S. homotropus, S. violaceus and S. amabilis. }{ }^{25-26}\end{array}$ \\
\hline 11 & $\begin{array}{l}\text { Reported chemical constituents } \\
\text { from other Strobilanthes species }\end{array}$ & $\begin{array}{l}\text { Lupeol was isolated from } S \text {. callosus and } S \text {. ixiocephala. Trypanthrin, indigo and indirubin were found in } S \text {. cusia. Caffeic } \\
\text { acid, p-hydroxy benzoic acid, p-voumeric acid, vanilic acid, gentinic acid, ferulic acid, syryngic acid, } \beta \text {-sitosterol and } \\
\text { stigmasterol were isolated from S. crispus. }{ }^{6,27-30}\end{array}$ \\
\hline 12 & $\begin{array}{l}\text { Reported biological activities of } \\
\text { other Strobilanthes species }\end{array}$ & $\begin{array}{l}\text { The plant } S \text {. cusia commonly known as banlangen was reported to possess antipyretic, antiviral, anti-inflammatory } \\
\text { and antiinfluenza activities. }{ }^{31} \text { S. crispus has been used as antidiabetic, antilytic, laxative, anti AIDS, antileukemic and } \\
\text { hepatitis. }{ }^{2-5,32}\end{array}$ \\
\hline
\end{tabular}


carried out by gradual addition of paraffin wax (m.p. $58-60{ }^{\circ} \mathrm{C}$ ) until TBA solution attained super saturation. The specimens were cast into paraffin blocks.

\section{Sectioning}

The paraffin embedded specimens were sectioned with the help of Rotary microtome. The thickness of the sections was $10-12 \mu \mathrm{m}$. Dewaxing of the sections was done by customary procedure. The sections were stained with toluidine blue. ${ }^{16}$ Since toluidine blue is a polychromatic stain, the staining results were remarkably good and some cytochemical reactions were also obtained. The dye rendered pink color to the cellulose walls, blue to the lignified cells, dark green to suberin, violet to the mucilage, blue to the protein bodies etc., wherever necessary sections were also stained with safranin, fast green and IKI (for starch).

For studying the stomatal morphology, venation pattern and trichome distribution, paradermal sections (section taken parallel to the surface of leaf) as well as clearing of leaf with $5 \%$ sodium hydroxide or epidermal peeling by partial maceration employing Jeffrey's maceration fluid were prepared..$^{15}$ Glycerin mounted temporary preparations were made for macerated/cleared materials. Powdered materials of different parts were cleared with sodium hydroxide and mounted in glycerin medium after staining. Different cell components were studied and measured.

\section{Photomicrographs}

Microscopic descriptions of tissues are supplemented with micrographs wherever necessary. Photographs of different magnifications were taken with Nickon labphoto 2 microscopic units. For normal observations bright field was used. For the study of crystals, starch grains lignified cells, and polarized light was employed. Since these structures have birefringent property, under polarized light they appear bright against dark back ground. Magnifications of the figures are indicated by the scale-bars. Descriptive terms of the anatomical features are as given in the standard anatomy textbooks. ${ }^{17-18}$

\section{Powder microscopy}

A few drops of chloral hydrate solution was added to a sample of powered plant material on a slide, covered with a glass slip and heated gently over a microbunsen. Vigorous boiling was avoided. The slide was examined under the microscope. When the clearing process is completed a drop of glycerol solution was added which will prevent crystallization of the mounting agent on cooling. ${ }^{19}$

\section{Physicochemical parameters}

Physicochemical analysis i.e., alcohol (90\% ethanol) and water soluble extractive values, total ash, acid-insoluble ash, water soluble ash and sulphated ash of the powdered drug were determined..$^{20-21}$

\section{Extraction}

\section{Pre-extraction}

The whole plant was washed thoroughly with water and separated into different parts viz stem, leaves, flowers and roots. These were shade dried and powdered separately using a mechanical blender before extraction.

\section{Successive extraction}

The powdered root and stem of S. kunthianus ( $500 \mathrm{~g}$ ) were extracted successively with $2.5 \mathrm{l}$ each of petroleum ether, chloroform, ethyl acetate and methanol in a Soxhlet apparatus separately for 18-20 $\mathrm{h}$. The extracts were concentrated in a rotary evaporator under reduced pressure at $35-40{ }^{\circ} \mathrm{C}$ and stored at $4{ }^{\circ} \mathrm{C}$ in a refrigerator till further use.

\section{Cold maceration}

The powdered leaves and flowers $(250 \mathrm{~g})$ were extracted with $1.5 \mathrm{l}$ of methanol by cold maceration separately by agitation for 7 days and filtered. The mass was squeezed out and again subjected for remaceration for 7 days and filtered off. The combined filtrate was concentrated as above.

\section{Crude extraction}

The powdered root, stem, leaves and flowers of S. kunthianus (500 g) were extracted separately with $2.5 \mathrm{l}$ of methanol in a Soxhlet apparatus for $18-20 \mathrm{~h}$. The extracts were concentrated as above.

\section{Phytochemical screening of $S$. kunthianus extracts}

A systematic and complete study of crude drugs should include a complete investigation of both primary and secondary metabolites derived from plant metabolism. The different qualitative chemical tests are to be performed for establishing profiles of given extracts for their nature of chemical composition. All the extracts obtained as above were tested for the following qualitative chemical tests for the identification of various phytoconstituents. .2-23 $^{22}$

\section{RESULTS}

\section{Macroscopic features}

The plant is profusely branched, compared to shrub. Young stem is angular with four ridges, the leaves are elliptic-lanceolate to obovate, 5 $\mathrm{cm}$ long and $3 \mathrm{~cm}$ wide; lamina is thick and coriaceous, dark green and scalerid above, reticulate and white villous on aseoles below; leaf margin are crenate-serrate; petiole is $1 \mathrm{~cm}$ long. Inflorescence is terminal or axillary, branched, unbranched spike. Bract and bracteoles are prominent, leafy; calyx has 5 sepals, gamosepalous, lobes are linear and lanceolate. Corolla is pale-blue to manne with 5 petals, gamopetalous, biloubed. Stamens: two, epipetalous, anthers dithecous, lobes parallel. Ovary is superior, bicarpellary, syncarpous, two ovules in each carpel. Seeds are densely hairy.

\section{Microscopic features}

\section{Leaf}

The leaf has thick, prominantly projecting midrib and lateral veins. The mid rib is $750 \mu \mathrm{m}$ in vertical planee and $800 \mu \mathrm{m}$ in horizontal plane. The mid rib has shallow median depression on the adaxial region; this part of the midrib has collenchymatous cells. The abaxial part has uneven and undulate outline; the epidermal layer is thin and continuous comprising of small squarish, thick walled cells. The ground tissue is parenchymatous; the cells are wide, angular, thin walled and compact. The vascular strand is small, single and consist of about eight parallel uniseriate rows of narrow xylem elements and wide thin phloem elements.

The lateral veins is bulbous and prominantly protrudes on the abaxial side of the lamina. It is $650 \mu \mathrm{m}$ vertically and $500 \mu \mathrm{m}$ horizontally. It has narrow, small celled epidermal layer and wide, angular copact parenchymatous groud tissue. The vascular strand is small, single and arc-shaped; it has four five short, thin rows of xylem elements and deep bowl-shaped line of phloem elements (Figure 2).

\section{Lamina}

The lamina is glabarous and smooth on the adaxial side and densely hairy on the abaxial side. The adaxial epidermis is quite wide; the cells are vertically oblong with thin anticlinal walls and thick cuticle on the outer tangential walls. The epidermis is $40 \mu \mathrm{m}$ thick. Some of the epidermal cells are further dilated into wide circular or horizontally 
elongated lithocysts possessing single, narrowly cylindrical rod like calcium carbonate cystolith. They are $170 \mu \mathrm{m}$ long and $120 \mu \mathrm{m}$ thick.

The abaxial epidermis is narrow with cylindrical cells. It bears dense covering type epidermal trichomes and less frequantly glandular trichomes. The glandular trichomes have small epidermal basal cell, short, narrow stalk cell and capitate type secretory body cells. They have four or eight cells and possess dense cytoplasam and prominent

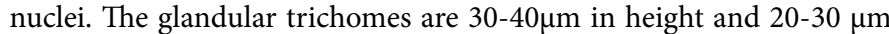
wide. They occur both on the adaxial and abaxial side of the lamina. The mesophyll consists of cylindrical compact, narrow pillars of palisade cells which are $50 \mu \mathrm{m}$ in height. The spongy parenchyma zone is narrow comprising of three or four spherical or lobed cells (Figure 3).

\section{Petiole}

The petiole is wide pot-shaped in sectional view with flat adaxial side, short thick lateral wings on the adaxial part. The epidermal cell layer is thin with small cubical cells. Linear to the epidermal layer are two or three layer of collenchyma at the adaxial side and six or seven layers of collenchyma at the abaxial side. The ground tissue is parenchymatous, homogeneous and the cells are circular to angular, thin walled and compact.

These is a single, wide, bowl-shaped vascular strand which consists of numerous, thin parallel files of angular, thick walled xylem elements lying on the outer part of the xylem. The petiole is $1.2 \mathrm{~mm}$ in vertical and $2.3 \mathrm{~mm}$ in horizontal planes. The vascular strand is $150 \mu \mathrm{m}$ thick (Figure 4).

\section{Stem}

The young stem is somewhat four angled measuring about $3 \mathrm{~mm}$ thick. It has thin epidermal layer of small squarish cells bearing dense trichomes. The cortex is $250 \mu \mathrm{m}$ wide and is differentiated into outer zone of parenchymatous cells. A thin median layer of cells in the cortex is chloenchymatous.

The vascular cylinder is thin, hollow and four-angled. It consists of short, narrow, circular radical files of xylem elements and xylem fibres.
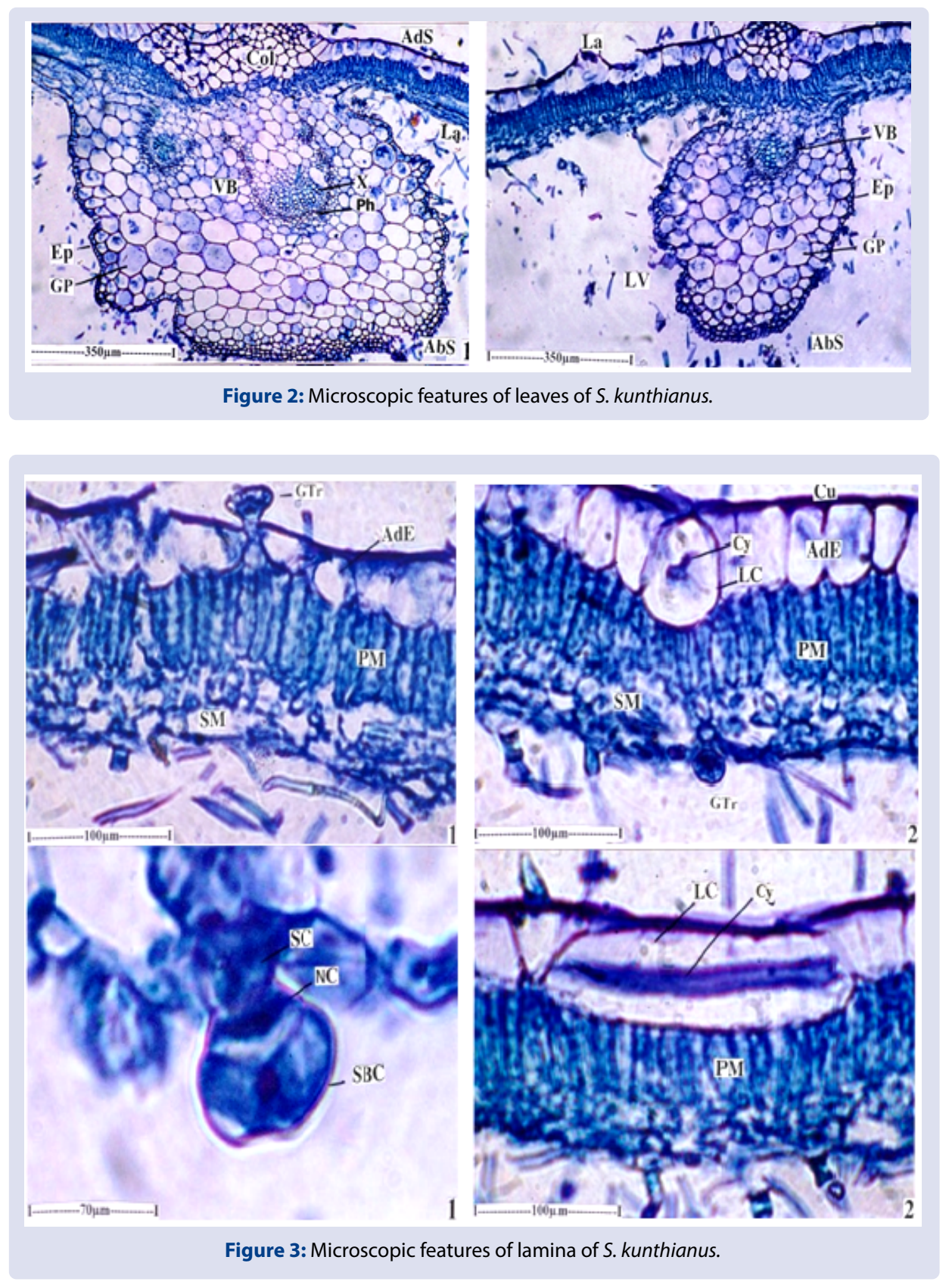
All along the outer part of the xylem cylinder occurs the phloem zone which has sieve elements and parenchyma cells. The vascular cylinder is $250 \mu \mathrm{m}$ thick. The pith is homogeneous and parenchymatous with thin walled compact angular parenchyma tissue (Figure 5).

\section{Thick stem}

The old and thick stem becomes circular in cross-sectional outline. It has cortex of $250 \mu \mathrm{m}$ wide, narrow continuous zone of phloem of $50 \mu \mathrm{m}$ wide and thick and dense secondary xylem $(350 \mu \mathrm{m}$ wide) enclosing a wide central pith.

The cortex is homogeneous having ellipitical tangentially stretched parenchyma cells. Secondary phloem has wide angular sieve elements and phloem parenchyma. Secondary xylem has narrow, circular thick walled vessels; they are solitary and diffusely distributed. The vessels are up to $20 \mu \mathrm{m}$ wide. Xylem fibers are angular in sectional view, thick
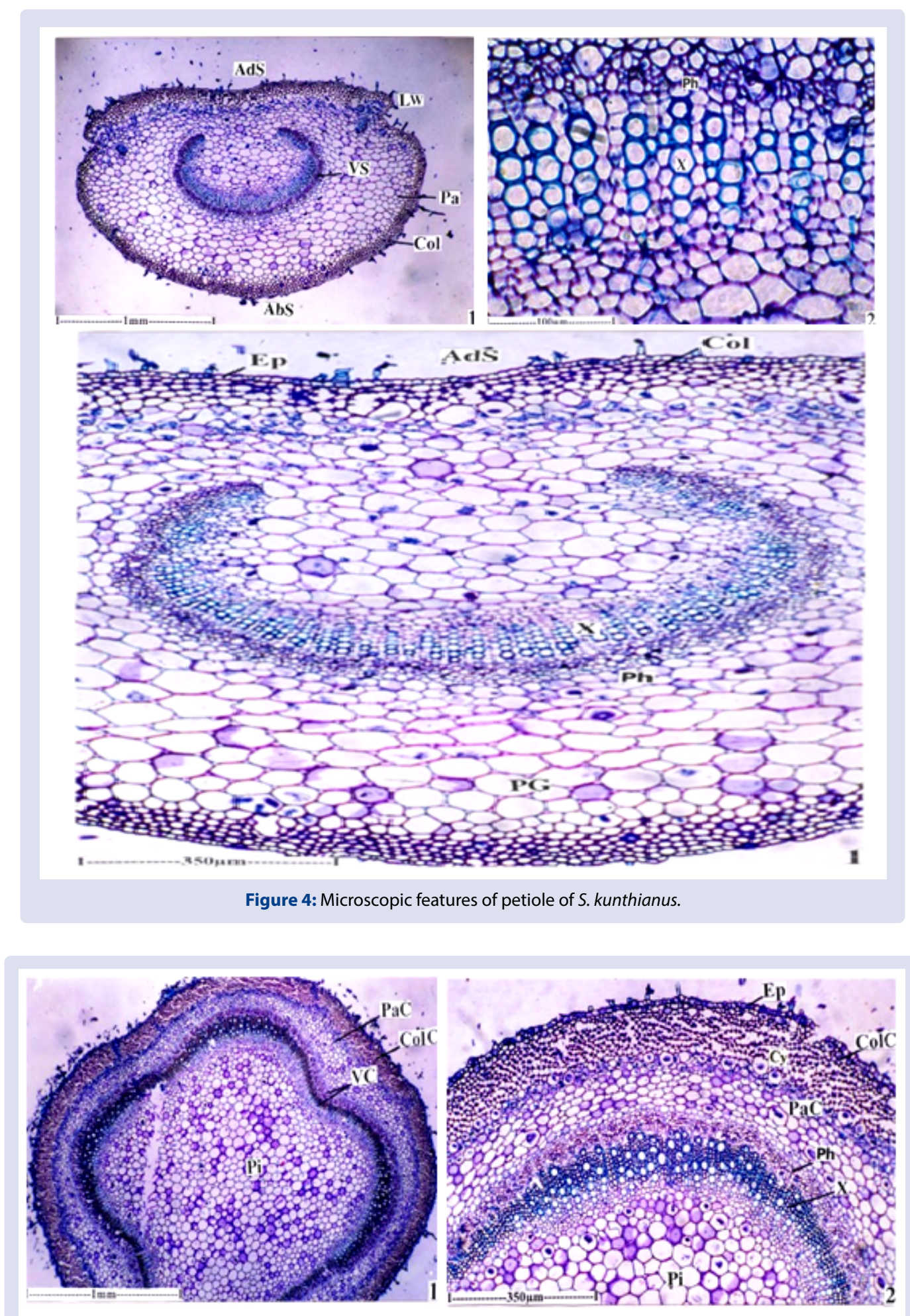

Figure 5: Microscopic features of stem of S. kunthianus. 
walled and lignified; they occur in regular radial rows. Xylem rays are one cell thick and are straight. The rays cell are also thick walled and lignified (Figure 6).

\section{Root}

The root has rough and uneven outer surface. Periderm is seen at discontinuous places and it is not continuous. The cortex has outer zone of circular, wide, less compact parenchyma cells; the liner zone of cortex has wide gaps of empty chambers and the cells further towards interior are nitaet, elliptical and compact. Secondary phloem is narrow and continuous. It has large, radial files of phloem elements (Figure 7).

\section{Secondary xylem}

Secondary xylem has dense, diffuse wide, circular vessels distributed among thick walled fibers. The diameter of the vessels increase gradually towards the periphery and it measures $40 \mu \mathrm{m}$ wide. The pith is narrow and nitaet. It is parenchymatous, comprises of thin walled circular compact cells (Figure 8).

\section{Venation}

The secondary and tertiary veins are thin and less prominent. The venation system is obscured blue to dense outgrowth of the epidermal trichomes. The vein-islets are wide and polygonal in outline. Distinct vein-terminations are not evident (Figure 9).

\section{Powder microscopy}

The powder exhibits fibers and vessel elements. The vessel elements are long, narrowly cylindrical and have long or short tails. The elements are 600-650 $\mu \mathrm{m}$ long. They have simple, oblique perforatious at the ends. The lateral walls have wide, circular, alternate pits.
The fibers are liberiforus type, having thick lignified walls. They are narrow with pointed ends and narrow lumens. The lumen is $10 \mu \mathrm{m}$ in wide. These are also septate fibers, which have wide lumen and thin septa; cell inclusions are often seen in the septate fibers. The septate fibers are $20 \mu \mathrm{m}$ wide.

Cystoliths are frequently seen in the powder. They are narrow, elongated, and blunt at one end and pointed at other. The surface is warty. The cytolith is $60 \mu \mathrm{m}$ thick and $700 \mu \mathrm{m}$ long (Figure 10).

\section{Physicochemical constant}

The percentage yield of different types of ash and extractive values of flowers, root, stem and leaves of $S$. kunthianus powdered material are given in the Table 2 . The total ash, water soluble ash, sulphated ash and alcohol soluble extractive values of the leaves of S. kunthianus were found to be high when compared to the other plant materials. The acid insoluble ash was found to be high in root and water soluble extractive value in flowers.

\section{Preliminary qualitative phytochemical studies}

The preliminary phytochemical study results were shown in Tables 3 and 4 . The successive petroleum ether and chloroform extracts of stem and root were found to contain phenolics, steroids and triterpenoids. The successive ethyl acetate and methanol extracts of stem were found to contain flavonoids, glycosides and phenolics. These two solvent extracts in root showed the presence of glycosides, phenolics and saponins. The macerated methanolic leaves extract showed the presence of glycosides, phenolics, steroids, triterpenoids and tannins. Along with these alkaloids, flavonoids, saponins and tannins were found to be present in macerated and crude methanol extracts of the flowers. The

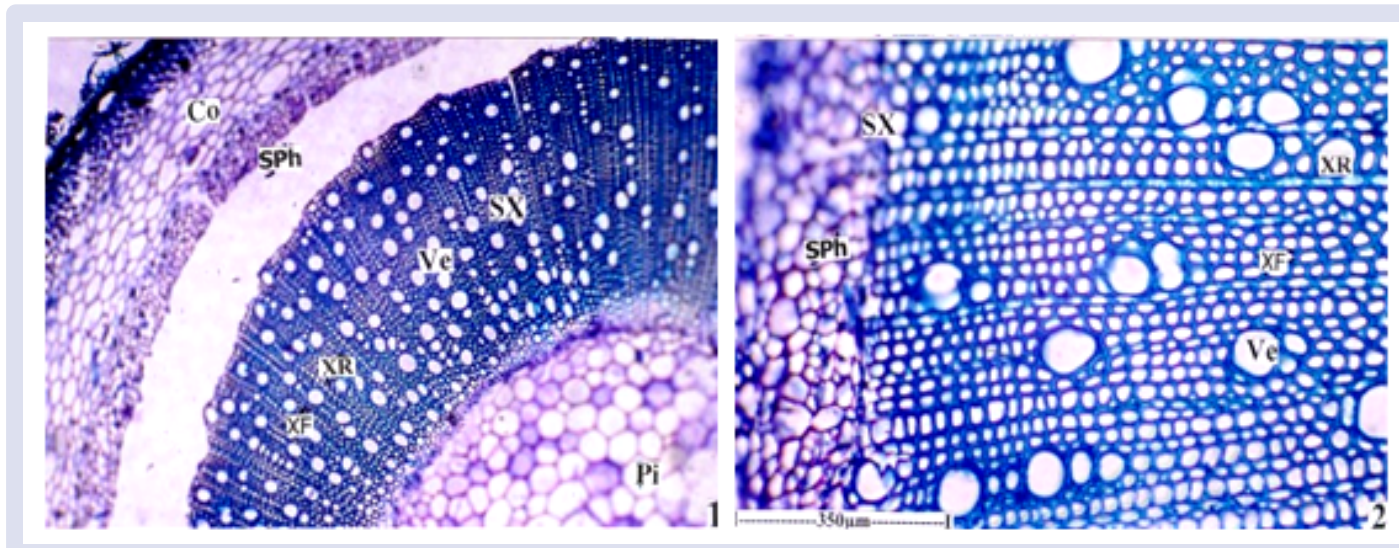

Figure 6: Microscopic features of thick stem of S. kunthianus.

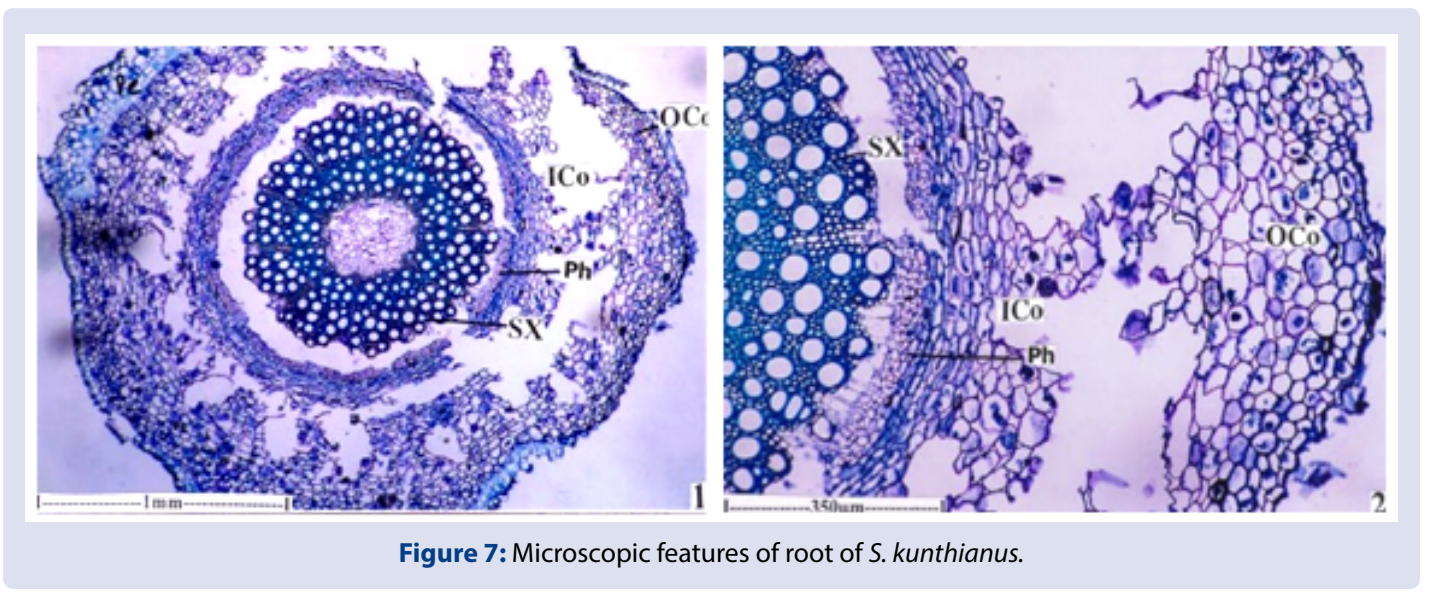




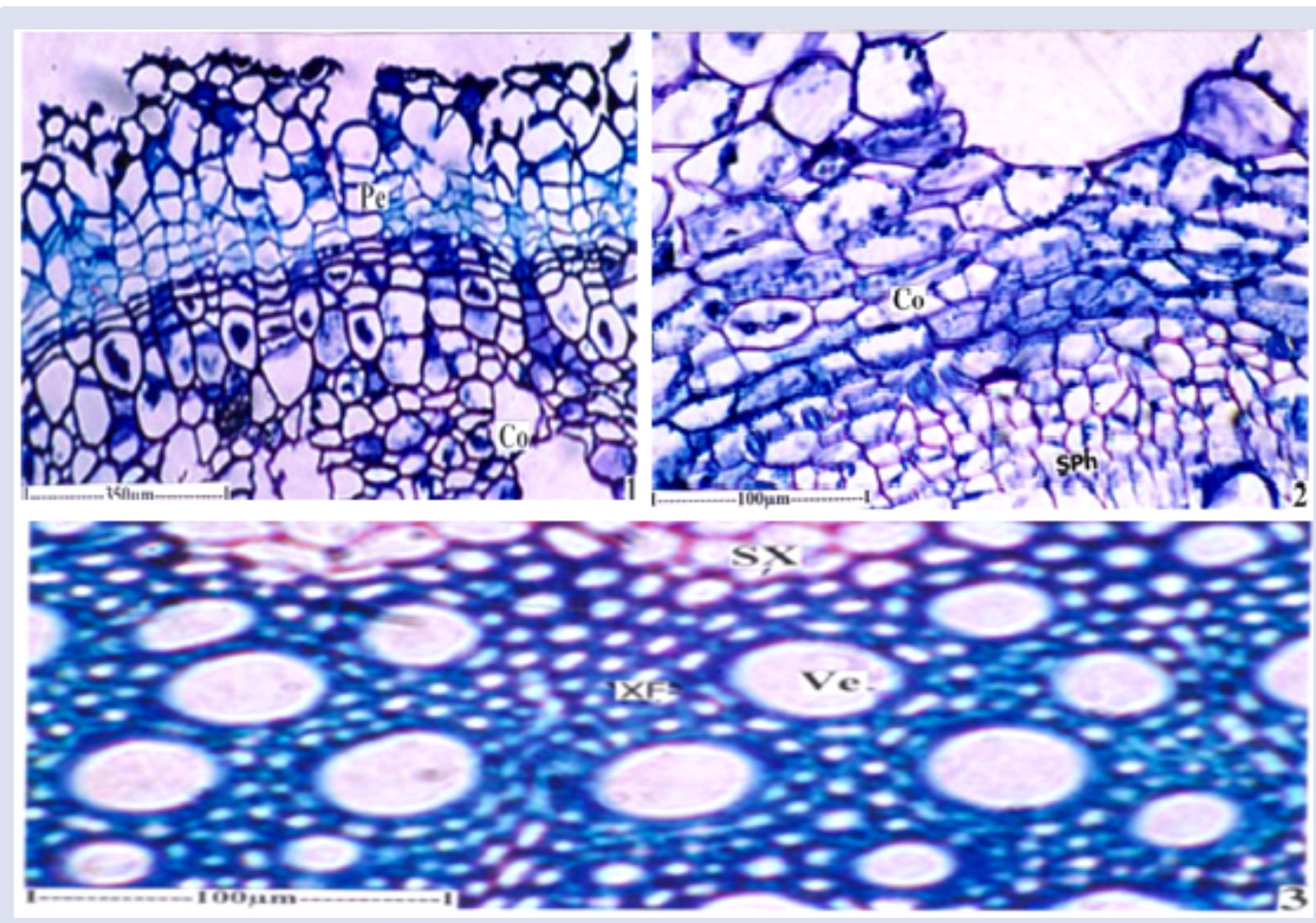

Figure 8: Microscopic features of xylem and pith of S. kunthianus.

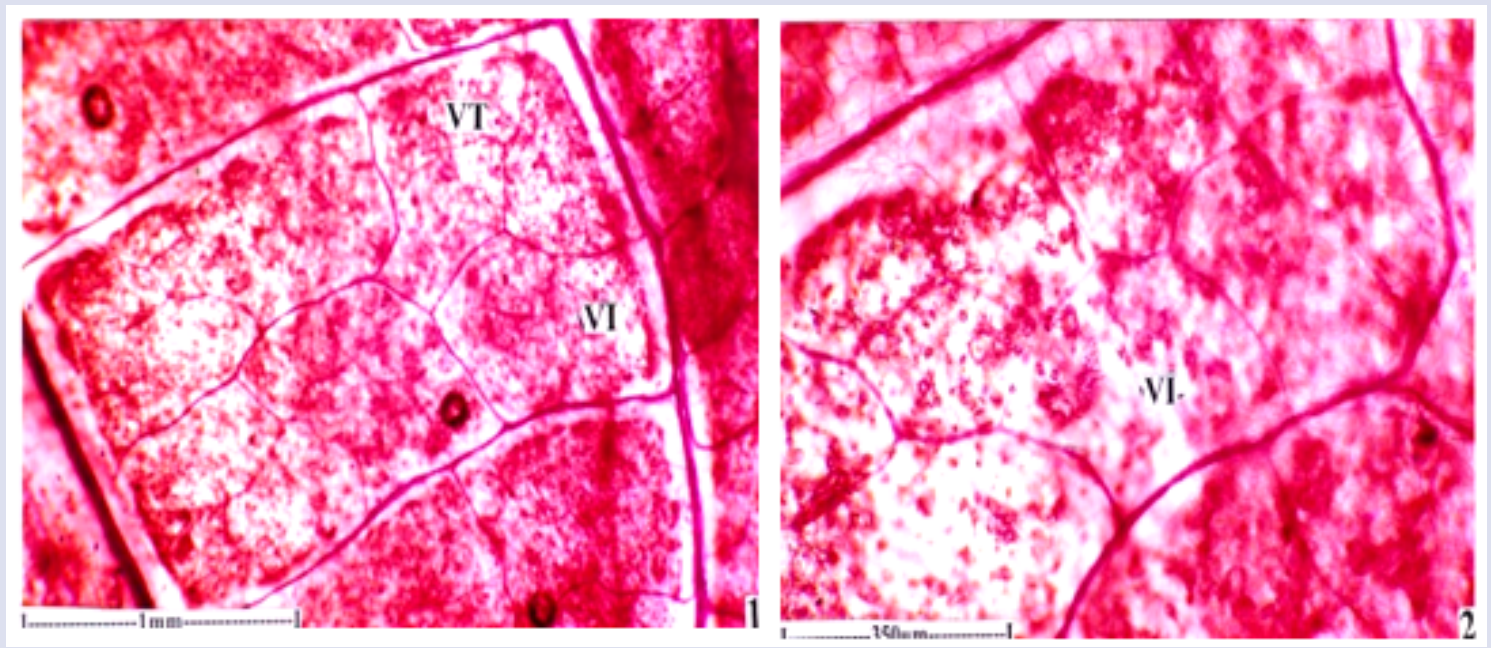

Figure 9: Microscopic features of vein of S. kunthianus.

Table 2: Physicochemical constants of S. kunthianus.

\begin{tabular}{cccccccc}
\hline \multirow{2}{*}{ S. No } & \multirow{2}{*}{ Plant materials } & \multicolumn{5}{c}{ Ash values $(\% \mathrm{w} / \mathrm{w})$} \\
\cline { 2 - 7 } & Total ash & Acid Insoluble ash & Water Soluble ash & Sulphated ash & Alcohol soluble & Water soluble \\
\hline 1 & Flower & $6.61 \pm 0.03$ & $0.08 \pm 0.01$ & $1.52 \pm 0.14$ & $0.12 \pm 0.01$ & $1.02 \pm 0.05$ & $10.32 \pm 0.08$ \\
2 & Root & $5.10 \pm 0.13$ & $2.06 \pm 0.02$ & $0.76 \pm 0.05$ & $0.23 \pm 0.02$ & $1.09 \pm 0.04$ & $2.30 \pm 0.06$ \\
3 & Stem & $2.99 \pm 0.02$ & $1.40 \pm 0.02$ & $0.38 \pm 0.04$ & $1.11 \pm 0.06$ & $0.73 \pm 0.05$ & $5.14 \pm 0.09$ \\
4 & Leaf & $20.49 \pm 0.31$ & $1.06 \pm 0.03$ & $4.05 \pm 0.10$ & $3.22 \pm 0.09$ & $1.64 \pm 0.12$ & $3.43 \pm 0.03$ \\
\hline
\end{tabular}

Average of three determinations, mean \pm SEM 


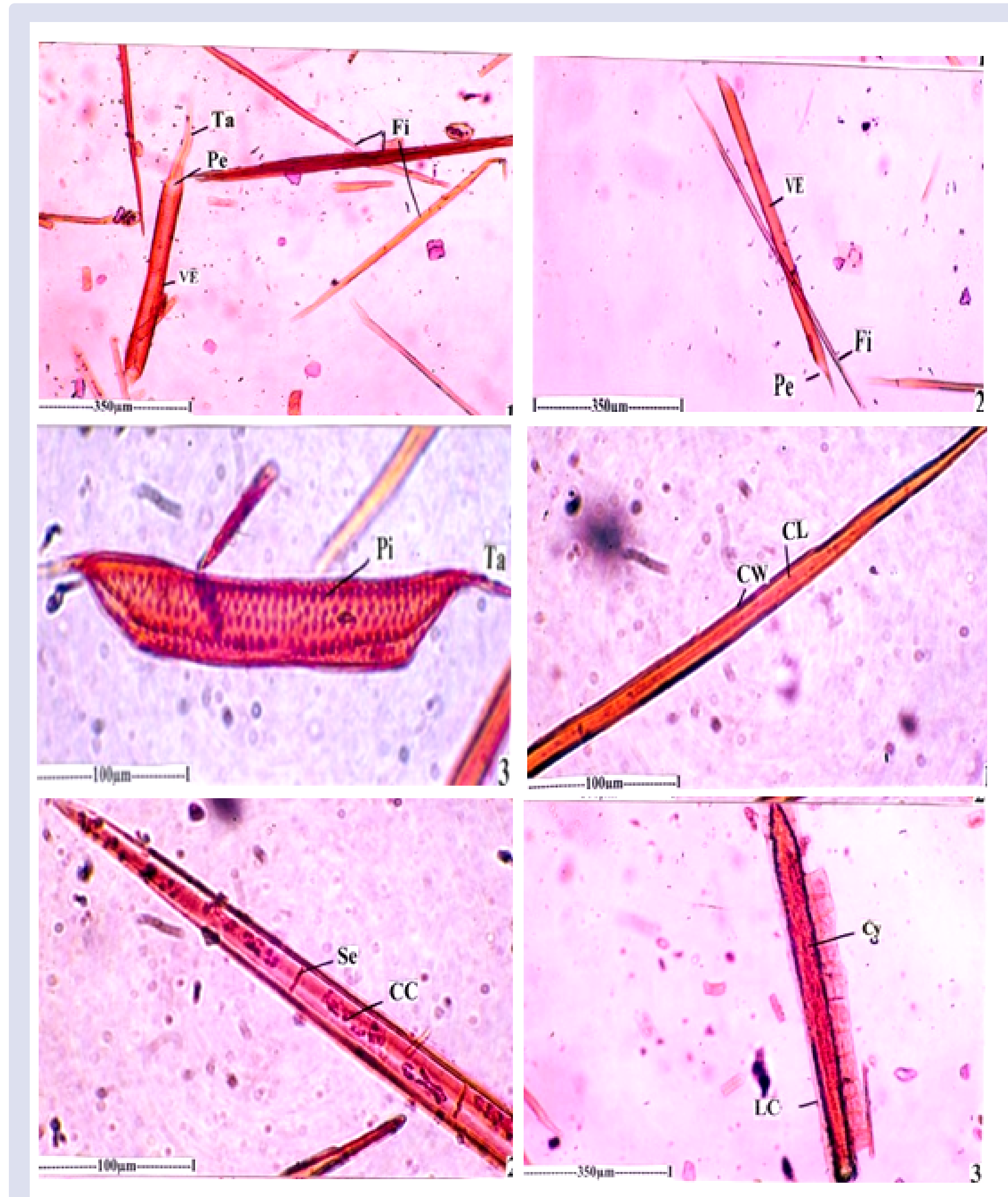

Figure 10: Powder microscopy of S. kunthianus. 
Table 3: Percentage yield and qualitative phytochemical analysis of successive extracts of stem and root of $S$. kunthianus.

\begin{tabular}{|c|c|c|c|c|c|c|c|c|c|c|}
\hline \multirow[b]{2}{*}{ Extract } & \multirow[b]{2}{*}{ Nature } & \multirow[b]{2}{*}{$\%$ Yield } & \multicolumn{8}{|c|}{ Phytoconstituents } \\
\hline & & & $\frac{\frac{n}{0}}{\frac{0}{0}}$ & $\begin{array}{l}\frac{n}{0} \\
\frac{0}{0} \\
\frac{0}{0} \\
\frac{\pi}{4}\end{array}$ & 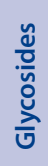 & $\begin{array}{l}\frac{\tilde{v}}{\overline{0}} \\
\frac{\bar{d}}{\Delta} \\
\frac{c}{\alpha}\end{array}$ & 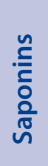 & $\begin{array}{l}\frac{n}{0} \\
\frac{0}{0} \\
\dot{\nu} \\
\text { ñ }\end{array}$ & 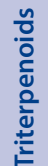 & 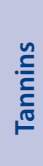 \\
\hline \multicolumn{11}{|l|}{ Successive stem extracts } \\
\hline Petroleum ether & Greenish yellow powder & 3.00 & - & - & - & + & - & + & + & - \\
\hline Chloroform & Dark green sticky & 0.95 & - & - & - & + & - & + & + & - \\
\hline Ethyl acetate & Dark green sticky & 0.60 & - & + & + & + & - & - & - & - \\
\hline Methanol & Greenish black sticky & 2.95 & - & + & + & + & - & - & - & + \\
\hline \multicolumn{11}{|l|}{ Successive root extracts } \\
\hline Petroleum ether & Yellowish white powder & 3.20 & - & - & - & + & - & + & + & - \\
\hline Chloroform & Pale brown sticky & 1.10 & - & - & - & + & + & + & + & - \\
\hline Ethyl acetate & Reddish brown sticky & 0.90 & - & - & + & + & + & - & + & - \\
\hline Methanol & Brown semi solid & 2.42 & - & - & + & + & + & - & - & - \\
\hline
\end{tabular}

+ Present, - Absent

Table 4: Percentage yield and qualitative phytochemical analysis of methanol extracts of S. kunthianus.

\begin{tabular}{|c|c|c|c|c|c|c|c|c|c|c|}
\hline \multirow[b]{2}{*}{ Extract } & \multirow[b]{2}{*}{ Nature } & \multirow[b]{2}{*}{$\%$ Yield } & \multicolumn{8}{|c|}{ Phytoconstituents } \\
\hline & & & $\frac{\frac{n}{0}}{\frac{0}{0}}$ & $\begin{array}{l}\frac{n}{0} \\
\frac{0}{0} \\
\frac{0}{0} \\
\frac{\pi}{4}\end{array}$ & 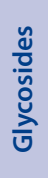 & $\begin{array}{l}\frac{\tilde{y}}{0} \\
\frac{\grave{Q}}{d} \\
\frac{\check{c}}{\alpha}\end{array}$ & 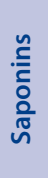 & $\begin{array}{l}\frac{n}{0} \\
\frac{0}{0} \\
\dot{\nu} \\
\tilde{n}\end{array}$ & 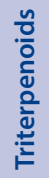 & 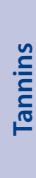 \\
\hline Macerated leaves extract & Greenish black sticky & 4.60 & - & - & + & + & - & + & + & + \\
\hline Macerated flower extract & Reddish brown sticky & 3.05 & + & + & + & + & + & + & - & + \\
\hline Crude flower extract & Dark reddish brown sticky & 19.60 & + & + & + & + & + & + & + & + \\
\hline Crude stem extract & Dark green sticky & 9.85 & - & - & + & + & - & + & + & - \\
\hline Crude root extract & Pale brown semi solid & 4.80 & - & + & + & + & - & - & - & - \\
\hline Crude leaves extract & Dark greenish black & 12.80 & - & - & + & + & - & + & + & + \\
\hline
\end{tabular}

+ Present, - Absent

crude methanol extracts of the stem and the leaves contain glycosides, phenolics, steroids and triterpenoids. The crude methanol extract of the root showed the presence of flavonoids, glycosides and phenolics.

\section{DISCUSSION}

Quality and reproduction of the total spectrum of constituents of the herbal drugs are extremely important. The herbal raw material often show a natural variability due to many external influences such as climate, soil quality, harvesting and drying conditions, with the consequence that the qualitative and quantitative composition varies from batch to batch from harvest to harvest, in particular. Plant identity can be achieved by macro and microscopical examination. Microscopical evaluation is indispensable in the initial identification of herbs, as well as in identifying small fragments of crude or powdered herbs and detection of foreign matter and adulterants. Hence, pharmacognostical studies were carried out with a focus on bringing out diagnostic character will be of immense help in proper identification, which play an important role in the standardization of plant materials. A detailed study of microscopic characters of all the parts such as leaves, flower, stem and root along with the photographs of the special characters taken during the study serves in identifying the plant. The microscopic features of leaves, lamina, petiole, stem, root, xylem, pith and vein islet were studied. The powder microscopy was also studied.

Determination of physicochemical constants is important for the purpose of evaluation of crude drugs. The total ash, water soluble ash, sulphated ash and alcohol soluble extractive values of the leaves of $S$. kunthianus were found to be high when compared to the other plant materials. The acid insoluble ash was found to be high in root and water soluble extractive value in flowers.

Preliminary phytochemical analysis is used for the purpose of evaluation of crude drugs. The four successive extracts of root and stem and six methanol extracts were tested for their phytoconstituents. Phenolics, steroids and triterpenoids were found in successive petroleum ether and chloroform extracts of stem and root. Glycosides and phenolics were found in ethyl acetate and methanol stem and root extracts and all the methanol extracts. The present results were well correlates with Singh et al., 2014, ${ }^{10}$ reported that the methanolic flower extract of $S$. kunthianus showed the presence of alkaloids, carbohydrates, phytosterols, tannins, proteins and flavonoids.

The microscopic evaluation of various parts of $S$. kunthianus and its extractive values, ash values of the powdered drug and preliminary physico-chemical and phytochemical screening that have been carried out which would be of considerable use in the identification of $S$. kunthianus. The percent extractives in different solvents indicate the quantity and nature of constituents in the extracts. The extractive values are also helpful in estimation of specific constituents soluble in particular solvent. This findings are useful to supplement the existing information with regard to identification and standardization of $S$. kunthianus even in the powdered form of the plant drug to distinguish it from drug and adulterant. These studies also suggest that the observed 
pharmacognostic, physiochemical and phytochemical parameters are of great value in the quality control and formulation development.

\section{CONCLUSION}

Pharmacognostical evaluation of the various plant parts of S. kunthianus was carried out in order to establish the identity and to standardize the plant. Microscopical characters of leaves, flowers, stem and root were studied. Physicochemical parameters like total ash, acid insoluble ash, water soluble ash and sulphated ash values and extractive values like alcohol soluble and water soluble were determined. Preliminary phytochemical analysis was carried out. Glycosides and phenolics were found in successive ethyl acetate and methanol stem and root extracts and all the crude methanol extracts. The present study may be useful to supplement the information with regard to its standardization, identification, and in carrying out further research and its use in Ayurveda system of medicine.

\section{CONFLICTS OF INTEREST}

None.

\section{REFERENCES}

1. Anonymous. Macroscopic and Microscopic Examination: Quality Control Methods for Medicinal Plant Materials. Geneva: WHO; 1998.

2. Sunarto PA. Materia Medica Indonesia. 1st Ed. Penerbitan Directorate Jenderwal Pengawasen Obat dan Makanan Jakarta, 1977.

3. Kushumoto JT, Shimadu N, Kakiuchi M, Hattori M, Namba T. Inhibitory effects of Indonesian Plant extracts on reverse transcriptase of an RNA tumour virus (I). Phytother Res. 1992;6:241-4

4. Ismail M, Manickam E, Dania A, Rahmat A, Yahaya A. Chemical composition and antioxidant activity of Strobilanthes crispus leaf extract. J Nut Biochem. 2000;11:536-42.

5. Jaksa S, Rahmat A, Obhman F, Ismail P, Mansor SM. Cancer induction and effect of Strobilanthes crispus leaf extract on liver histology and enzymes changes in rats. J Trop Plants. 2004;5:187-92.

6. Rahmat A, Edvini S, Ismail P, Yunthin T, Abu Bakar M. Chemical constituents, antioxidant activity and cytotoxic effects of essential oil from Strobilanthes inspus and Lawsonia inermis. J Biol Sci. 2006;6:1005-10.

7. Nair RB, Ravishankar B, Vijayan NP, Sasikala CK, Saraswathy VN. Antiinflammatory effect of Strobilanthes heyneanus leaves a biochemical study. J Res Ayurveda and siddha. 1988;9:49-58.

8. Desu BSR, Elango K, Satish Kumar MN, Suresh B, Manimaran S, Nanjan MJ. In-vitro anti-inflammatory and anti-osteoarthritic activities of Strobilanthes kunthianus and Strobilanthes cuspidatus. Int J Res Pharm Chem. $2011 ; 1(4): 1265-8$

9. Desu BSR, Elango K, Satish Kumar MN, Suresh B, Manimaran S, Nanjan MJ. Analgesic activity of Strobilanthes kunthianus and Strobilanthes cuspidatus. Int J Res Pharm Biomed Sci. 2012;3(1):435-8.

10. Singh BB, Das S, Maithi A. Antioxidant Property for lipophilic extract of Strobilanthes kunthiana flowers. Indian J Res Pharm Biotech. 2014;2(1):1005-9.
11. Everlyne IM, Darsini DTP, Yadav SA. Unraveling antibiofilm potency of Strobilanthes kunthiana Nees T. Anderson ex Benth against throat-infectious methicillin-resistant Staphylococcus aureus. Indo American J Pharma Res. 2016;6(6):5707-16.

12. Rajasekaran A, Loganathan $\mathrm{V}$, Jaewanth A, Jayakar B. Central nervous activity of Strobilanthes kunthiana leaf. Hamdard Medicus. 2000;43(1)38-40.

13. Singh DN, Verma N, Kulshreshtha DK, Agrawal AK. In-vitro antigiardial activity of ethanolic extract and fractions from Phlebophyllum kunthianum. J Nat Remedies. 2012;12(1):68-71.

14. Everlyne IM, Sangilimuthu AY, Darsini DTP. Spectral analyses of the bioactive compounds present in the ethanolic leaf extract of Strobilanthes kunthiana (Nees) T. Anderson ex Benth. Adv Biores. 2015;6(3)65-71.

15. Sass JE. Elements of Botanical Microtechnique. McGraw Hill Book Co, New York. 1940;222.

16. O'Brien TP, Feder N, Me Cull, ME. Polychromatic staining of plant cell walls by toluidine blue-O. Protoplasma. 1964;59:364-73.

17. Easu K. Plant Anatomy. John Wiley and sons, New York, 1964:767.

18. Easu K. Anatomy of seed Plants. John Wiley and sons, New York, 1979:550.

19. Shah G, Chawla A, Baghel US, Rahar S, Singh PS, Dhawan RK. Pharmacognostic standardization of leaves of Melaleuca leucadendron. Pharmacog J. 2013;3:1438.

20. Gupta AK. Quality Standards of Indian Medicinal Plants. vol. 1. New Delhi: Indian Council of Medical Research. 2003:236-7.

21. The Indian Pharmacopoeia. vol. 2. New Delhi: Controller of Publications 1996:A53-4.

22. Harborne JB. Phytochemical Methods. Chapman and Hall, New York 1984:12375.

23. Kokate CK. Practical Pharmacognosy, Vallabh Prakashan, New Delhi, India 1997:107-11.

24. Venu P. Strobilanthes Blume (Acanthaceae) in Peninsular India. The Flora of India - IV, BSI, Kolkata, 2006:129-31.

25. Fyson PY. The Flora of the South Indian Hill Stations 1, Today and Tomorrows Print and Publishers, New Delhi, 1932:444-52.

26. Anonymous. The wealth of India, Raw materials, CSIR, Publication and Information Directorate, New Delhi, 1976.

27. Agarwal RB, Rangari VD. Antiinflammatory and antiarthritic activities of lupeol and $19 \alpha-\mathrm{H}$ lupeol isolated from Strobilanthus callosus and Strbilanthus ixocephala roots. Indian J Pharmacol. 2003;35(6):384-7.

28. Liau BC, Jong TT, Lee MR, Chen SS. LP - APCI - MS method for detection and analysis of trypanthrin, indigo and indirubin in Daginagye and Banlangen. $J$ Pharm Biomed Anal. 2007;43:346-51.

29. Soediro I, Pellecuer J, Andary C, Privat G. Strobilanthes crispus (L) BI.I: Premerikesaan Senyacoann turunan asa, kafeat verbacosid. Acta pharma Indonesia. 1983;VIII:1-10.

30. Soediro I, Pellecuer J, Andary C, Privat G. Strobilanthes crispus (L) BI.I: Premerikesaan Senyacoann turunan asa, kafeat verbacosid. Acta pharma Indonesia. 1987;XII:1-7.

31. Ho YL, Chang YS. Studies on the antinociceptive, anti-inflammatory and antipyretic effects of Isatis indigotica root. Phytomed. 2002;9:419- 24.

32. Yogespiriya S, Hanachi P, Patimah R, Asmah R, Fanziah O. Histological study during hepatocarciniogenesis in rats treated with Strobilanthes crispus extract. J Biol Sci. 2005;2:153-7. 


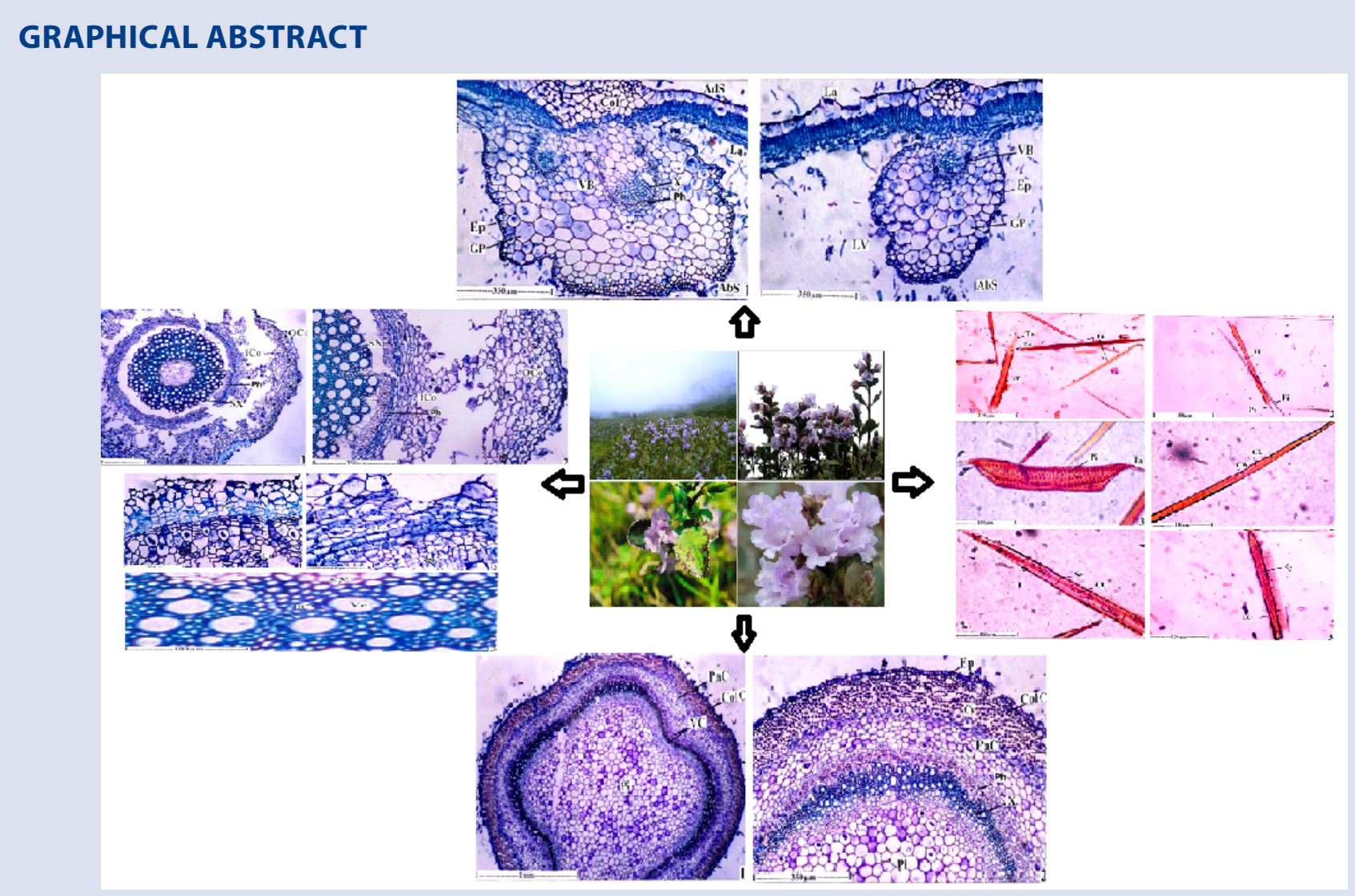

\section{ABOUT AUTHORS}

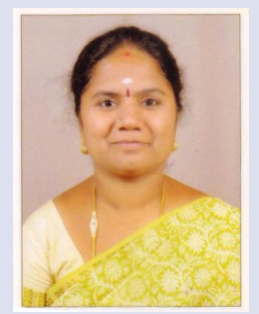

Geetha Balasubramaniam completed her PhD in 2012 at JSS College of Pharmacy, JSS Academy of Higher Education and Research, Udhagamandalam, Tamilnadu, India. She is currently working as a Professor in the Department of Pharmaceutical Chemistry, Swamy Vivekanandha College of Pharmacy, Tamilnadu, India. Her research interest is isolation of active constituents from medicinal plants and study about its biological properties.

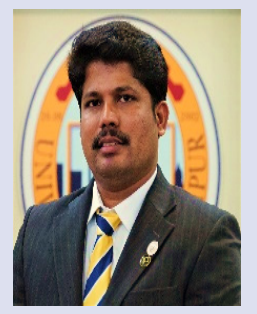

Mahendran Sekar is currently working as Associate Professor in Department of Pharmaceutical Chemistry, Faculty of Pharmacy and Health Sciences, Universiti Kuala Lumpur Royal College of Medicine Perak, Ipoh, Perak, Malaysia. His research is mainly in the field of drug discovery and development of natural products. His research interest is isolation of active constituents from medicinal plants and study about its biological properties.

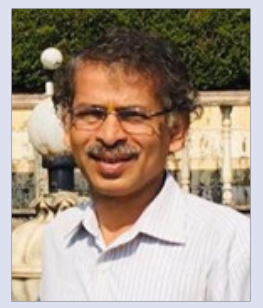

Shrishailappa Badami is currently a proprietor of Chaitanya Vikas Yoga \& Nature Cure Centre, Dharwad, Karnataka, India. His research is mainly in the field of drug discovery and development of natural products. His research interest is isolation of active constituents from medicinal plants and study about its biological properties. At present he is active in manufacturing of herbal products and made it available commercially in the local market.

Cite this article: Balasubramaniam G, Sekar M, Badami S. Pharmacognostical, Physicochemical and Phytochemical Evaluation of Strobilanthes kunthianus (Acanthaceae). Pharmacogn J. 2020;12(4):731-41. 